\title{
Anti-Nociceptive Activity of Achillea Wilhelmsii Ethanolic Extract in Mice
}

\author{
Mohammadmehdi Hassanzadeh-Taheri ${ }^{1}$, Mohammad Hassanpour-Fard ${ }^{2}$, Abulfazl Ahani ${ }^{3}$ and Mehran \\ Hosseini $^{1 *}$ \\ ${ }^{1}$ Cellular and Molecular Research Center, Birjand University of Medical Sciences, Iran \\ ${ }^{2}$ Department of Pharmacology, Birjand University of Medical Sciences, Iran \\ ${ }^{3}$ General Practitioner, Birjand University of Medical Sciences, Iran
}

Submission: March 16, 2018; Published: August 06, 2018

*Corresponding author: Mehran Hosseini, Cellular and Molecular Research Center, Birjand University of Medical Sciences, Birjand, Ira, Phn: 00985632381206; Fax: 0098-56-32433004; Email: mehranhosseiny@yahoo.co.in; mehranhosseiny@bums.ac.ir

\begin{abstract}
Aim: The aerial parts of Achillea wilhelmsii C. Koch (AW) have been used in Persian medicine for pain relief. However, as far as we know no scientific study has been done to support its efficacy. The aim of present study was to investigate the anti-nociceptive activity of ethanolic extract of AW in mice.

Material and Methods: Acute oral toxicity was evaluated based on guideline 425 of the Organization of Economic and Cooperation and Development (OECD). Accordingly, a single $2 \mathrm{~g} / \mathrm{kg}$ oral dose of ethanolic extract of AW was administrated to 6 female Wistar rats. Anti-nociceptive activity of AW (100-30mg/kg, i.p) was investigated using the hot-plate test in male BALB/c mice.

Results: The extract was well tolerated as no signs of toxicity or death were observed during the period of observation. AW just in maximum dose $(300 \mathrm{mg} / \mathrm{kg})$ significantly increased latency time on the hot-plate test 30 and 90 minutes after administration. The anti-nociceptive activity of AW at the dose of $300 \mathrm{mg} / \mathrm{kg}$ was comparable to the reference drug (morphine $5 \mathrm{mg} / \mathrm{kg}$ ) at 60 minutes after administration while at 30 as well as 120 minutes time points the anti-nociceptive activity of morphine was superior.
\end{abstract}

Conclusion: The results of the current study provide evidence suggesting AW possesses anti-nociceptive activity and also provide the pharmacological basis for its uses in traditional medicine for pain relief.

Keywords: Achillea wilhelmsi; Anti-nociceptive; mice;

\section{Introduction}

The term 'pain' generally defined as an unpleasant sensory and emotional experience associated with actual or potential tissue damage, caused by intense or damaging stimuli [1]. At some points of life, everyone experiences pain. It is an enormous global health problem and has been estimated that one-fifth adults suffer from pain, globally [2]. There are many herbal medicines for natural pain relief and some of them have been approved in experimental studies [3,4]. Over the past two decades, there has been a tremendous increase in the use of herbal medicine worldwide. It has been estimated that threequarters of world population use herbal medicine. Despite this interest, there is still a significant lack of research data in this field [5-7].

Achillea wilhelmsii C. Koch (A. wilhelmsii) is one of the widespread plant species in Iran (Figure 1) [8]. Many studies have been conducted to evaluate the medicinal efficacy of different extracts of this herb. It has been approved that Achillea wilhelmsii has antimicrobial, antiproliferative, antihypertensive and vagolytic activities [9]. In some parts of Iran, the aerial parts of the plant have been traditionally used for the treatment of stomach pain $[9,10]$ and undocumented reports also suggest that it has been prescribed for pain relief. Phytochemical studies have shown that aerial parts of Achillea wilhelmsii consist of flavonoids, alkaloids (achilleine), cineol, borneol, $\alpha$ - and $\beta$-pinen, camphor, caryophyllene, thujene, rutin, sesquiterpenoids, and monoterpenoids [11-13]. However, scientific studies supporting the analgesic potential of Achillea wilhelmsii aerial parts are lacking and the present study aimed to investigate the antinociceptive effect of ethanolic extract of aerial parts of Achillea wilhelmsii in mice. 


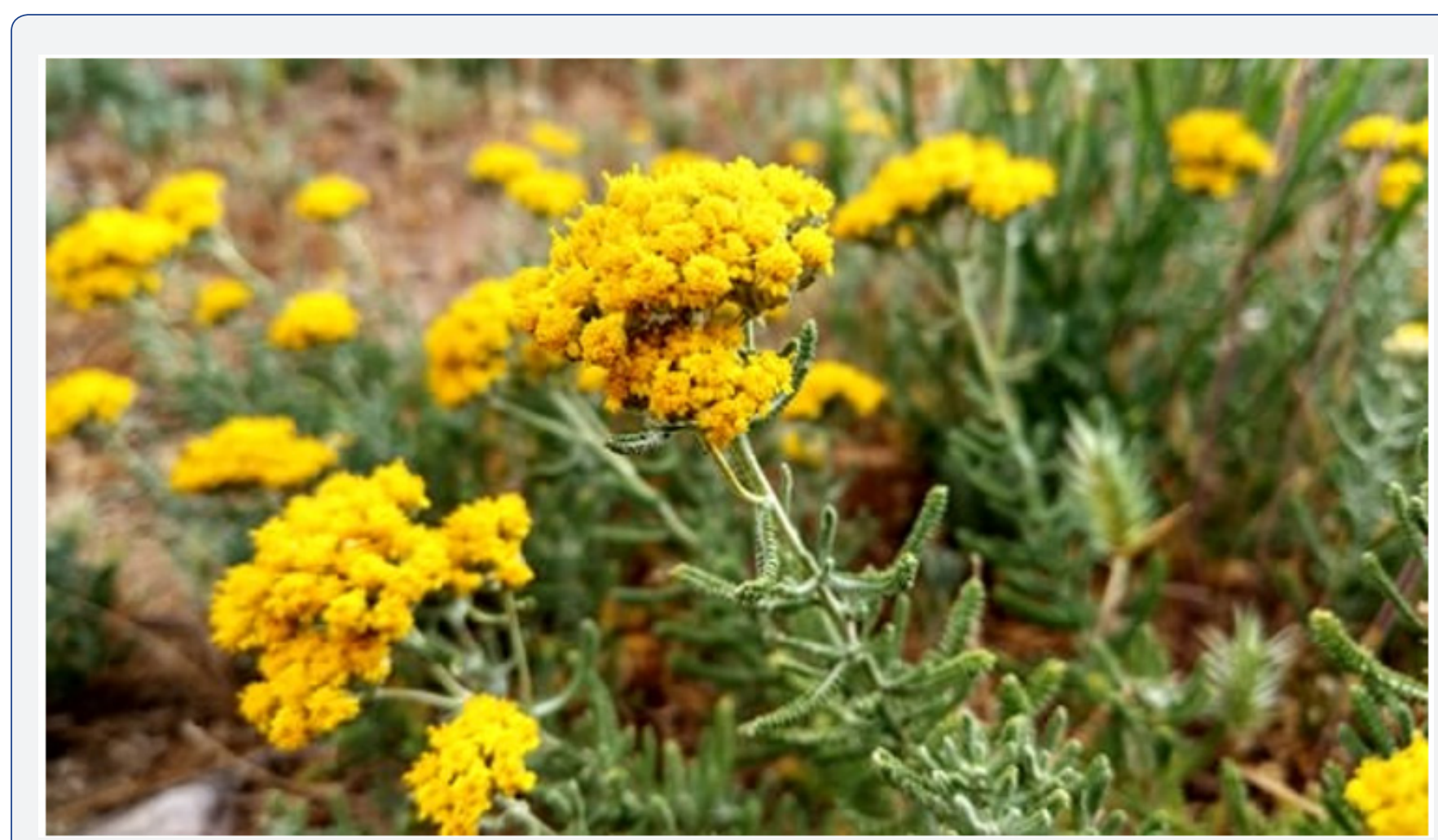

Figure 1: Achillea wilhelmsii C. Koch in the flowering stage (May 2017), Gookchin village, South Khorasan Province, Iran.(33.070908 $\left.59.555114^{\circ} \mathrm{E}\right)$.

\section{Material and Methods}

\section{Extract preparation}

Achillea wilhelmsii C. Koch (AW) aerial parts were purchased from the traditional local market in Birjand, Iran. After identification of the plant by an expert botanist the voucher specimen (327) was kept in the herbarium of Birjand University, Faculty of agriculture, Birjand, Iran. The plant aerial parts (stem, leaves and flowers) were dried in shade and at the room temperature and powdered using an electric miller. To prepare the ethanolic extract, 100 grams of the powder was macerated in $80 \%$ ethanol $(1000 \mathrm{ml})$ with constant stirring for 48 hours at room temperature. Afterwards, the mixture was filtered (Whatman Grade 589, Blue Ribbon, Germany), and $10 \mathrm{ml}$ of concentrated extract was transferred and dried in a Petri dish at a temperature of $40{ }^{\circ} \mathrm{C}[14]$. The yield of the dried extract was about $12 \mathrm{~g}$ per $100 \mathrm{~g}$ of dried plant.

\section{Animals}

Forty male BALB/c mice weighing 25-30g (10 weeks old) were obtained from the laboratory animal facility of Research Centre of Experimental Medicine at Birjand University of Medical Sciences, Iran. The animals were housed in polypropylene cages and maintained under standard laboratory conditions [temperature-controlled room $\left(22 \pm 2{ }^{\circ} \mathrm{C}\right)$ with a $12 \mathrm{~h}$ light/ dark cycle], free access to commercial animal chow (Behparvar, Iran) and tap water. All animal procedures were conducted in accordance with the guide for the laboratory animals care and usage approved by the Ethics Committee of the Brjand University of Medical Sciences (Ethic code: Ir.bums.REC.1394.15). Also, all efforts were made to minimize animal suffering and to reduce the number of animals used.

\section{Acute toxicity}

After 8 hours of fasting, a single oral dose of the ethanolic extract of AW at the dose of $2000 \mathrm{mg} / \mathrm{kg}$ was administered to one female Wistar rat (8-week old) and at intervals of 48 $\mathrm{h}$, the same dose was given to five other animals, totalling 6 female treated rats. Simultaneously, a control group $(n=6)$ was treated with vehicle solution (saline) to establish a comparative negative control (NC) group [15]. For 14 consecutive days after the administration, the animals were monitored to evaluate behavioral parameters include; conscious state (general activity); motor system coordination and muscle toning (response to tail touch and grip, straightening, strength to grab); reflexes (corneal and headset); central nervous system activities (Straub, convulsions, tremors, sedation, anesthesia and ataxia) and activities on the autonomic nervous system (lacrimation, cyanosis, ptosis, salivation and piloerection) (Table 1). 


\section{Journal of Complementary Medicine \& Alternative Healthcare}

Table 1: Anti-nociceptive effects of ethanolic extract of Achillea wilhelmsii (AW) or morphine on the hot plate test in mice.

\begin{tabular}{|c|c|c|c|c|}
\hline \multirow{2}{*}{ Groups } & \multicolumn{4}{|c|}{ Reaction Time (S) } \\
\cline { 2 - 5 } & Baseline & $\mathbf{3 0} \mathbf{~ m i n}$ & $\mathbf{6 0} \mathbf{~ m i n}$ & $\mathbf{1 2 0} \mathbf{m i n}$ \\
\hline Control & $4.55 \pm 1.48$ & $5.78 \pm 1.75$ & $4.48 \pm 1.20$ & $6.08 \pm 1.10$ \\
\hline Morphine $(5 \mathrm{mg} / \mathrm{kg})$ & $4.88 \pm 1.28$ & $11.53 \pm 3.18^{* *}$ & $9.76 \pm 1.90^{* *}$ & $9.51 \pm 2.49^{*}$ \\
\hline $\mathrm{AW}(100 \mathrm{mg} / \mathrm{kg})$ & $4.35 \pm 1.42$ & $5.96 \pm 1.89$ & $6.37 \pm 2.27$ & $5.46 \pm 0.86$ \\
\hline $\mathrm{AW}(200 \mathrm{mg} / \mathrm{kg})$ & $4.56 \pm 1.56$ & $6.00 \pm 0.81$ & $6.36 \pm 1.73$ & $6.20 \pm 1.70$ \\
\hline $\mathrm{AW}(300 \mathrm{mg} / \mathrm{kg})$ & $4.38 \pm 1.42$ & $8.85 \pm 1.21^{*}$ & $9.56 \pm 2.18^{* *}$ & $7.23 \pm 2.39$ \\
\hline
\end{tabular}

Data were reported as mean $\pm S D$ of eight animals. ${ }^{*} p<0.05$, and ${ }^{* *} p<0.001$ vs vehicle-treated mice (control).

\section{Anti-nociceptive assay}

The hot-plate test was performed using a hot-plate analgesiometer (TOI, Iran) maintained at $55 \pm 0.5^{\circ} \mathrm{C}$. Forty mice that showed nociceptive responses within 10 S placing on the hotplate were selected and randomly allocated into 5 equal groups ( $\mathrm{n}=8$ each) as follow: group 1 received $0.2 \mathrm{~mL}$ normal saline and served as control (C); group 2 received morphine sulfate $(5 \mathrm{mg} / \mathrm{kg})$ as the standard drug (MOR); and groups 3-5 received ethanolic extract of AW at the doses of 100, 200 and $300 \mathrm{mg} / \mathrm{kg}$ respectively. All treatments were administrated intraperitoneally (i.p) in the same volume $(0.2 \mathrm{~mL})$. Mice were placed on the hotplate equipment and their latency to the thermal stimulus was recorded at 30,60 , and 120 min post-treatment. Reaction time was taken as the interval between the instant the animal was placed on the plate till the moment it began to lick its paws or raise its hands.

\section{Statistical analysis}

The data were statistically analyzed using SPSS software, version 22. Hypothesis testing was by one-way analysis of variance followed by Tukey post-hoc test. Statistical significance was inferred at $\mathrm{p}<0.05$.

\section{Results}

\section{Acute toxicity evaluation}

Likewise to the control group, ethanolic extract of AW at the dose of $2000 \mathrm{mg} / \mathrm{kg}$ did not cause death in the animals. There was no difference in behavioral parameters between control and AW $(2000 \mathrm{mg} / \mathrm{kg})$ treated group. It is very crucial to evaluate acute toxicity signs in attempt to establish a lethal dose causing $50 \%$ of animals death (LD50). According to this assay, it was assumed that AW LD50 dose is above $2000 \mathrm{mg} / \mathrm{kg}$.

\section{Anti-nociceptive evaluation}

The results show that AW only at the maximum dose $(300 \mathrm{mg} / \mathrm{kg})$ increased the reaction time 30 and 60 minutes after administration. (30': $8.85 \pm 1.21 \mathrm{~s} ; 60^{\prime}: 9.56 \pm 2.18 \mathrm{~s}$ when compared to control (30': $\left.5.78 \pm 1.75 \mathrm{~s} ; 60^{\prime}: 4.48 \pm 1.20 \mathrm{~s}\right)(\mathrm{p}<0.05$ or $\mathrm{p}<0.001)$ like morphine $\left(30^{\prime} ; 11.53 \pm 3.18 \mathrm{~s}, 60^{\prime}: 9.76 \pm 1.90\right)$ ( $\mathrm{p}<0.001$ ). $120 \mathrm{~min}$ after investigation only morphine received mice had significantly higher latency time in comparison with control group $(\mathrm{p}<0.05)$. AW at 100 and $200 \mathrm{mg} / \mathrm{kg}$ doses did not exhibit any significant anti-nociceptive activity at all of the studied time points.

\section{Discussion}

Toxicological evaluation in experimental animals usually was categorized into four classes: acute, subacute, subchronic and chronic. Acute toxicity test is defined as a single exposure for less than $24 \mathrm{~h}$. The oral route of drug administration is the most convenient and commonly used method for toxicity evaluations in pre-clinical animal models [16]. The results of acute toxicity assay showed that AW at dose of $2000 \mathrm{mg} / \mathrm{kg}$ did not cause death and behavioral changes in the animals. Therefore, it can be concluded that according to OECD guidance, the ethanolic extract of AW may be assigned to be the lowest toxicity class 5 (LD50> 2000mg/kg).

According to phytochemical studies, different parts of AW exhibited wide range of compounds among which the major constituents are a-thujene (6.11\%), a-pinene (5.11\%), sabinene (5.23\%), p-cymene (7\%), 1,8-cineole (6\%), linalool (10\%), camphor (8.43\%), thymol (18.98\%) and carvacrol (20.13\%) [17]. Moreover, previous studies show that AW has remarkable antioxidant activity [18]. The main compound of AW is carvacrol (CVL) that its antibacterial activity mainly on several bacteria strains, e.g. Escherichia coli and Bacillus cereus have proven [19]. Moreover, a study led by Quintans-Júnior in 2012 reported CVL (50 or $100 \mathrm{mg} / \mathrm{kg}$; i.p.) inhibited the development of mechanical hypernociception and edema induced by carrageenan and TNF- $\alpha$; however, no effect was observed on hypernociception induced by PGE2 (Prostaglandin E2) and dopamine. They concluded that AW by antioxidant and anti-inflammatory properties could relieve pain and inflammation in mice [20]. The other main compound of AW is thymol. Interestingly, our finding is in good agreement with the study conducted by FachiniQueiroz in which the effects of thymol and CVL were tested on ear edema and carrageenan-induced pleurisy in rats. Their results demonstrated that in the pleurisy model, CVL and thymol significantly inhibited inflammatory edema. However, in the ear edema model, only CVL (10mg/ear), reduced edema formation, exerting a topical anti-inflammatory effect and thymol $(10 \mathrm{mg} /$ ear) did not reduce edema formation but rather presented an irritative response. They concluded that thymol and CVL have antagonist effects [21]. CVL may be the compound responsible for the anti-nociceptive effects of AW. 


\section{Conclusion}

In conclusion, the evidence from this study supports the idea that Achillea Wilhelmsii has anti-nociceptive potential. The present study is the first step and has only investigated the antinociceptive effect of the plant in hot-plate test. Future work will need to be undertaken to elucidate mechanisms by which Achillea Wilhelmsii could relieve pain and inflammation.

\section{Acknowledgement}

This work was supported by a grant from Birjand University of Medical Sciences, Iran (no.757). We would like to thank Mr. Mohsen Pouyan, Birjand University, for confirming identification of the plant.

\section{References}

1. Merskey HE (1979) Classification of chronic pain: descriptions of chronic pain syndromes and definitions of pain terms. Pain 6(3): 247-8.

2. Brennan F, Carr D B, Cousins M (2007) Pain management: a fundamental human right. Anesthesia \& Analgesia 105(1): 205-21.

3. Ahani A, Hassanzadeh-Taheri M, Hosseini M, Hassanpour-Fard M (2017) Antinociceptive and Anti-inflammatory Activities of Iris songarica Schrenk Rhizome Ethanolic Extract in Mice. Arak Medical University Journal 20(8): 9-19.

4. Bahmani M, Shirzad H, Majlesi M, Shahinfard N, Rafieian-Kopaei M (2014) A review study on analgesic applications of Iranian medicinal plants. Asian Pacific journal of tropical medicine 7 (Supp1): S43-S53.

5. Laelago T, Yohannes T, Lemango F (2016) Prevalence of herbal medicine use and associated factors among pregnant women attending antenatal care at public health facilities in Hossana Town, Southern Ethiopia: facility based cross sectional study. Archives of Public Health 74(1): 7.

6. Hassanzadeh-Taheri M, Hassanpour-Fard M, Doostabadi M, Moodi H, Vazifeshenas-Darmiyan K, et al. (2018) Co-administration effects of aqueous extract of turnip leaf and metformin in diabetic rats. Journal of traditional and complementary medicine 8(1): 178-183.

7. Hassanzadeh-Taheri M, Hosseini M, Hassanpour-Fard M, Ghiravani Z, Vazifeshenas-Darmiyan K, et al. (2016) Effect of turnip leaf and root extracts on renal function in diabetic rats. Oriental Pharmacy and Experimental Medicine 16(4): 279-286.

8. Nekoei M, Mohammadhosseini M (2016) Chemical Compositions of the Essential Oils from the Aerial Parts of Achillea wilhelmsii Using Traditional Hydrodistillation, Microwave Assisted Hydro-distillation and Solvent-Free Microwave Extraction Methods: Comparison with the Volatile Compounds Obtained by Headspace Solid-Phase Microextraction. Journal of Essential Oil Bearing Plants 19(1): 59-75.

9. Niazmand S, Khooshnood E, Derakhshan M (2010) Effects of Achillea wilhelmsii on rat's gastric acid output at basal, vagotomized, and vagalstimulated conditions. Pharmacognosy magazine 6(24): 282-285.

10. Nemeth E, Bernath J (2008) Biological activities of yarrow species (Achillea spp.). Curr Pharm Des 14(29): 3151-3167.

11. Afsharypuor S, Asgary S, Lockwood GB (1996) Constituents of the essential oil of Achillea wilhelmsii from Iran. Planta Med 62(1): 77-78.

12. Dokhani S, Cottrell T, Khajeddin J, Mazza G (2005) Analysis of aroma and phenolic components of selected Achillea species. Plant Foods Hum Nutr 60(2): 55-62.

13. Javidnia K, Miri R, Sadeghpour H (2004) Composition of the volatile oil of Achillea wilhelmsii C. Koch from Iran. DARU Journal of Pharmaceutical Sciences 12(2): 63-66.

14. Fard MH, Naseh G, Lotfi N, Hosseini SM, Hosseini M (2015) Effects of aqueous extract of turnip leaf (Brassica rapa) in alloxan-induced diabetic rats. Avicenna journal of phytomedicine 5(2):148-156.

15. OECD (2008). Test No. 425: Acute Oral Toxicity: Up-and-Down Procedure: OECD Publishing.

16. Hassanzadeh-Taheri M, Hosseini M, Salimi M, Moodi H, Dorranipour D (2018) Acute and sub-acute oral toxicity evaluation of Astragalus hamosus seedpod ethanolic extract in Wistar rats. Pharmaceutical Sciences 24(1): 23-30.

17. Kazemi M, Rostami H (2015) Chemical composition and biological activities of Iranian Achillea wilhelmsii L. essential oil: a high effectiveness against Candida spp. and Escherichia strains. Natural Product Research 29(3): 286-288.

18. Alfatemi SMH, Rad JS, Rad MS, Mohsenzadeh S, da Silva JAT (2015) Chemical composition, antioxidant activity and in vitro antibacterial activity of Achillea wilhelmsii C. Koch essential oil on methicillinsusceptible and methicillin-resistant Staphylococcus aureus spp. 3 Biotech 5(1): 39-44

19. Pei Rs, Zhou F, Ji Bp, Xu J (2009) Evaluation of combined antibacterial effects of eugenol, cinnamaldehyde, thymol, and carvacrol against $\mathrm{E}$. coli with an improved method. Journal of food science 74(7): 379-83.

20. Guimarães AG, Xavier MA, de Santana MT, Camargo EA, Santos CA, et al. (2012) Carvacrol attenuates mechanical hypernociception and inflammatory response. Naunyn-Schmiedeberg's archives of pharmacology 385(3): 253-263.

21. Fachini-Queiroz FC, Kummer R, Estevao-Silva CF, Carvalho MDdB, Cunha JM, et al. (2012) Effects of thymol and carvacrol, constituents of Thymus vulgaris $\mathrm{L}$. essential oil, on the inflammatory response. Evidence-Based Complementary and Alternative Medicine 2012.

Your next submission with Juniper Publishers
will reach you the below assets
- Quality Editorial service
- Swift Peer Review
- Reprints availability
- E-prints Service
- Manuscript Podcast for convenient understanding
- Global attainment for your research
- Manuscript accessibility in different formats
( Pdf, E-pub, Full Text, Audio)
- Unceasing customer service
Track the below URL for one-step submission
https://juniperpublishers.com/online-submission.php

